Discovery of Seventy-one New Variable. Stars.-The wholesale discovery of new variable stars from photographic plates is proceeding at Harvard, and in Harvard College Observatory Circular, No. 130, Prof. Pickering announces the discovery of a further batch of seventy-one new variables. These were found by Miss Leavitt on the Harvard maps Nos. 9, 12, 21, 48, and 5I. Prof. Pickering gives a table showing the proportion of newly discovered variables the total number now known to exist in each region arined, and arrives at the general-deduction that about one-third of all the variables in the three northern regions examined, and about one-half of those in the two southern regions, yet remain to be found. The designations, positions, and magnitude ranges of the newly discovered variables are given, and the list includes thirteen probable Algol and seven long-period variables, the proportion of the former being remarkable, as in the case of Region 50 discussed in Circular No. 122.

The Electrical Action of the Sun.-In these columns for March 14 we referred to a discussion, by Dr. Albert Nodon, of the nature and effects of the sun's electrical charge. The whole discussion is now published as an extract from the Revue des Questions scientifiques for April and July, and will be found to be of great interest by all workers allar physics and the allied terrestrial phenomena. In the first part of the paper Dr. Nodon discusses the observations, the apparatus used in making them, and the theories deduced from them. The second part contains a discussion of the application of the results to the explanation of cometary, planetary, and terrestrial phenomena, whilst in the third part of the paper the author discusses the deductions relative to terrestrial physics. The paper is published by J. Polleunis, 45 rue Sans Souci, Brussels.

Micrometer Measures of Double Stars.-In No. 4193 of the Astronomische Nachrichten (p. 277, July 26) Dr. H. E. Lau publishes a further list of Struve double stars measured by hil self, and discusses the mean probable errors of his easurements. In addition to the eighty measures made by Dr. Lau, the list also contains twentyeight measures made by Herr Luplau-Jannsen.

\section{THE MAY OR GORSEDD YEAR IN ENGLISH AND WELSH FAIRS.}

SIR NORMAN LOCKYER has taygh y to call the year indicated by alignifents of fsponuments in Britain the May year. The duarter ay of that year are between th polstices and equfroxes. In fixing these dates, of course/the solar quarter days were marked as well, which yof jonvefiently called the solstitial year. It will cleafle way for the discussion of some figures bearing on the subject if the two series of quarter days are presented here side by side, as given in "Stonehenge Astronomically Considered," p. 23 :-

\begin{tabular}{lllllll} 
May Year & $\ldots$ & Feb. 4 & May 6 & Aug. 8 & \multicolumn{2}{c}{ Nov. 8} \\
Solstitial Year & ... March 21 & June 21 & Sept. 23 & Dec. 23
\end{tabular}

The quarter in both series is of the same length, ninetyone days, and the distance from a solstitial quarter day to a May-year one is roughly forty-five days.

Though the name May year is a very happy one, as the May festival was certainly the most popular, it is really the Gorsedd year, the very raison d'être for that institution which, in form, purpose, and ritual, is the temple-observatory brought up to date. We know now for what purpose the megalithic monuments were raised, and that knowledge has been acquired by working from the known to the unknown. By assuming that the Welsh Gorsedd is a much truer representation of ancient Druidism than the manifestly inaccurate, second-hand observations of Cæsar and other classical writers, we are able to see at the Welsh National Eisteddfod in this twentieth century the actual use to which the templeobservatory was put. If such a broad assertion causes surprise, that surprise is considerably lessened by what seems to me to be an incontrovertible fact, that, instead of having one Gorsedd, and that in Wales, a true survival from late Neolithic times (to fix an indubitable downward limit), we have in Britain more than one thousand Gorsedds the pedigrees of which are as unimpeachable as that of the Welsh institution. I refer to fairs still held on the quarter days of the May year. To a student of the Welsh Gorsedd this fact at once dispels any a priori doubt as to the antiquity of that institution. It is only one among a thousand, though, I would maintain; it is the only one that shows what all the others were at first.

The Gorsedd and the popular fair are one and the same, constituting a true monument as ancient as a templeobservatory in stone. A better way of putting it is, the temple-observatory has survived in (I) stone, in (2) tradition, and in (3) festival. The Welsh Gorsedd presents this triple evidence.

There is, I think, no need for a formal proof of the prevalence of the May year in Ireland, Scotland, and Wales, or the "Celtic fringes." It reigns supreme over still purely Celtic ground. It is when one comes to England proper that even one accustomed to mark time in May-year terms must confess to a feeling of surprise. The evidence from the Celtic fringes is, of course, indispensable to understand and explain the English May-year fairs, but a brief presentation of the English case may be helpful by way of enlisting the cooperation of English archæologists to make that case as strong as possible.

I take Owen's "New Book of Fairs" for 1824 as source. The book was published by Royal licence, but as regards Wales it is incomplete, and I would infer as much as regards England. 'The following figures, except those given by counties, include the Welsh fairs as given in the list. That inclusion cannot affect seriously the English case, as will be seen.

The relative popularity of the May and of the solstitial years may first be ascertained by comparing the number of all fairs in May with those in June. May fairs, 5to; June fairs, 250; 2 to I for May.

There are two lists of fairs in Owen's book, one by counties and the other by dates. I take the latter first: The figures in every case are my own. As the book is incomplete, and all lists of fairs I have consulted are so, I have thought it sufficient for the present purpose to make only one rapid reckoning of the fairs. The chief fair days can be easily noted by large groups of fairs. The fairs corresponding to the May-year festivals are to be looked for under several dates. The astronomical day is in many cases observed eleven and twelve days later. Generally, that day has given way to the first of the calendar month. In both cases new and old style dates must be noted. Then there are fairs depending on such dates. All fairs held during the first twelve days of the month should be numbered. In the case of November, the inclusion of Martinmas fairs needs no comment, as November $I_{1}$ is a Scottish quarter day, and the Scottish quarter days, with the fact that in Gaelic-speaking Scotland the months, as well as the seasons, are still reckoned in the true May-year order, is sufficient formal proof of the predominance of that year on Celtic ground.

\begin{tabular}{|c|c|c|c|c|c|c|c|c|c|c|}
\hline Februa & & Fairs & May & Fairs & August & & Fairs & Novem & ber & Fair \\
\hline 2 & $\ldots$ & 8 & I & ... 32 & I & $\ldots$ & 18 & I & $\ldots$ & 10 \\
\hline 5 & $\ldots$ & 7 & 4 & ... 42 & 2 & $\ldots$ & 29 & 6 & $\ldots$ & 13 \\
\hline 13 & $\ldots$ & 20 & 6 & ... 38 & 5 & $\ldots$ & 53 & 8 & $\ldots$ & 43 \\
\hline I 4 & $\ldots$ & 12 & 8 & $\ldots 14$ & 10 & $\ldots$ & 16 & 11 & $\ldots$ & 17 \\
\hline D. & $\ldots$ & 21 & I 2 & $\ldots 8 \mathrm{I}$ & I 2 & $\ldots$ & 26 & 12 & $\ldots$ & 26 \\
\hline & 一 & & I3 & $\ldots$ II & I5 & $\ldots$ & 13 & 13 & $\ldots$ & 14 \\
\hline & - & & I4 & .. 42 & D. & $\ldots$ & 50 & 17 & $\ldots$ & 18 \\
\hline & - & & 17 & $\ldots$ I6 & & - & & 22 & $\ldots$ & 43 \\
\hline & - & & 18 & $\ldots$ I 2 & & - & & D. & ... & 57 \\
\hline & - & & D. & $\ldots 7 \mathrm{I}$ & & - & & & - & \\
\hline & & 68 & & 359 & & & 205 & & & 241 \\
\hline
\end{tabular}

D. = Dependent fairs.

Thus we have 873 plain May-year fairs. I claim now the Church-year fairs, which are plainly the old May-year festivals. For February 4 I claim 28 fairs between Candlemas and the beginning of Lent; for May $6,35^{8}$ Whitsun and Ascension fairs; and for November 8, 53 fairs at Michaelmas, $7 \mathrm{I}$ on October io (Old Michaelmas), and 32 on December in (Old.St. Andrew's Day). Though Michaelmas and St. Andrew's Day are both a month away from November I, they constantly occur as half-year

N. ). 1975 , voL . 76 ] 
days corresponding to May Day. It is very likely, however, that some of the August fairs have been absorbed into Michaelmas. As that day occurs so near to the autumnal equinox, some concession must be made also to the solstitial year. There is no need, however, to decide these points at present.

We can now add 542 to our list of May-year fairs, altogether 1415 fairs which may reasonably be claimed as so many Gorsedds or prehistoric monuments, 96 in February, 717 in May, 205 in August, and 397 in November. It is curious to note that the number of plain May fairs and of Church-year May fairs is the same. The ratio for November seems to be too high, and the number for that month has grown evidently at the expense of August. Dividing the total for August and May, we get 3 or for each of those months to match the figure for May, which is always at least twice as high as the corresponding figures. For obvious reasons February is a poor time for fairs, and the intrusion of Lent has very generally broken up that end of the May year. A more thorough scrutiny will be the means of recovering many February 4 fairs.

If the above estimate is considered too generous, my estimate of the solstitial-year fairs must err more in that pleasing direction, for I include, against strong reasons, all the Easter fairs in that estimate.

\begin{tabular}{|c|c|c|c|c|c|c|c|c|c|}
\hline & & & & Fairs & & & & & Fairs \\
\hline March 2I & $\cdots$ & $\cdots$ & $\ldots$ & 2 & June $\mathbf{2 2}$ & $\ldots$ & $\ldots$ & $\ldots$ & 29 \\
\hline April 5 ... & $\ldots$ & $\cdots$ & $\ldots$ & 37 &,$\quad 24$ & $\ldots$ & $\ldots$ & $\cdots$ & 35 \\
\hline & & & & 39 & & & & & II 8 \\
\hline Easter & $\ldots$ & $\ldots$ & $\cdots$ & 231 & Trinity ... & $\cdots$ & $\ldots$ & $\ldots$ & 59 \\
\hline & & & & 270 & & & & & 177 \\
\hline & & & & Fairs & & & & & Fairs \\
\hline $\begin{array}{r}\text { Sept. } 19 \\
2 \text { II }\end{array}$ & $\cdots$ & $\cdots$ & $\cdots$ & $3^{t}$ & December & $2 \mathrm{I}$ & $\cdots$ & $\cdots$ & 7 \\
\hline Oct. $2^{2 \mathrm{I}}$ & $\cdots$ & $\cdots$ & $\cdots$ & 20 & , & 25 & $\cdots$ & $\cdots$ & 8 \\
\hline & $\cdots$ & $\cdots$ & $\cdots$ & 53 & & & & & \\
\hline & & & & IO4 & & & & & I 5 \\
\hline
\end{tabular}

There are, then, 276 true solstitial fairs and 347 Churchyear fairs to bring the total up to 623 ; but the figure for Easter shows evident borrowing from February, the vernal equinox, and May. A fair ratio would be obtained by counting sixty Easter fairs for the vernal equinox and the remainder for February.

In claiming the Easter fairs for the May year, I have a larger number of fairs to add to the solstitial estimate. Beside the May year, with the portions of the Church year which are evidently based on it, and the solstitial year as such, there are two other series of dates to consider. The one I would call the Roman year, being important dates in the old Roman year, which were early associated with the names of Christ, St. Mary, and at least six of the Apostles. I refer to groups of fairs on the $25^{\text {th }}$ of the month. There are 25 fairs on March 25 and 43 on September 25, 68 fairs which I would add to the solstitial estimate.

The other series of dates I would call the Petrine year, with groups of fairs on the 29th of the month. When the old Celtic saints of Llandaff Cathedral, Teilo and Dyvrig, May-year saints, were superseded in AngloNorman times by SS. Peter and Paul, June 29 was fixed as the beginning of the year in that cathedral. The canons there still mark their time of residence as from that date. The Petrine year is fairly general, though it is altogether subsequent to the middle of the twelfth century A.D., at any rate in South Wales. There are 18 fairs on March 29,35 on June 29,45 on July to (O.S.), 53 on September 29, and $7 \mathrm{I}$ on October ro (O.S.), in all ${ }^{25} \mathrm{I}$ fairs which I would add to the solstitial estimate, which now stands at 948 fairs.

The May year is still 467 ahead, and the May-year figures are certainly much more satisfactory than the large figures I have juggled for the solstitial estimate. If the latter is fairly correct, I must now add it in a lump to that of the May year, and say that we have still in England and Wales 2363 fairs, relics of festivals held at the same spots or thereabouts when the dates were obtained by direct solar observations by means of aligned monuments. Several capable archæologists have expressed the opinion, anent the astronomical theory, that they admit the solstitial alignments, while doubting the very existence of the May year in connection with the monuments. Such admission is substantially conplete. The solstices and equinoxes were of little direct practical use to the ancient farmer as dates to commence farming operations. The W'elsh farmer of to-day is finely indifferent to the almanac statements that spring begins on March 21 and winter on December 23. He knows better. The solstitial quarter days were observed as points from which the infinitely more practically important May quarter days could be correctly marked.

So far I have made only a rough preliminary reconnaissance of the list of fairs. I now take up Owen's list of fairs by counties, not to learn more about the relative prevalence of the May and the solstitial year so much as to learn more concerning the May year itself. Except May 6 and November 8, I have counted all fairs in February, May, August, and Noventber. From the Church year I have borrowed only solme pre-Lenten fairs for February and the Whitsun fairs for May. The total is just the same, but the analysis is much more to the point. The Welsh fairs are included, though the list is very defective. The letters F.M.A.N., variously grouped, represent May-year quarters :-

\begin{tabular}{|c|c|c|c|c|c|c|c|c|c|c|c|c|c|c|c|c|}
\hline & & 量 & ह & $\overbrace{4}^{\infty}$ & 茎 & 峁 & $\begin{array}{l}\infty \\
\dot{0} \\
\dot{z} \\
z\end{array}$ & & & $\begin{array}{l}\dot{4} \\
\sum \\
\Sigma\end{array}$ & 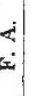 & $\begin{array}{l}\dot{4} \\
\dot{\Sigma} \\
\dot{\Sigma} \\
\dot{\Sigma}\end{array}$ & $\mid \begin{array}{l}z \mid z \\
\dot{z} \mid \dot{4}\end{array}$ & $\dot{z} \begin{array}{l}z \\
\dot{z} \\
\dot{x}\end{array}$ & 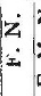 & 蓄 \\
\hline Bedford & & & 8 & & & & I & & & - & & & & & & \\
\hline rks ... & $\cdots$ & $\begin{array}{l}3 \\
2\end{array}$ & 7 & $\begin{array}{l}3 \\
2\end{array}$ & & $=$ & I & - & & - & 7 & & $1-$ & & & \\
\hline tcks & $\ldots$ & 3 & I I & 3 & 3 & 3 & I & - & & $-x$ & $t$ & - & $1-$ & - & - & - \\
\hline imbs & $\cdots$ & - & 3 & I & & & - & & & & & & -- & & & \\
\hline Cheshire & $\ldots$ & $\mathbf{I}$ & 9 & 7 & 7 & 2 & $\mathbf{I}$ & $-5+20$ & & & -. & 2 & & $1-$ & I & \\
\hline ornwall & & 7 & 27 & $1 \mathrm{I}$ & I7 & 2 & 3 & - & & & - & $2-$ & & $1-$ & I & \\
\hline Cumberlan & & i & 7 & 5 & 2 & - & - & $\perp$ & & & - & $2-$ & $2-$ & -- & - & \\
\hline Derby & $\cdots$ & 4 & 9 & 4 & 8 & 1 & I & $\mathbf{I}$ & $\mathbf{I}$ & 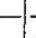 & 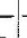 & 1 & - & $I$ & 2 & I \\
\hline Devon & $\cdots$ & 8. & 25 & $\mid 15$ & II & 2 & I & - & & - & 2 & $4-$ & & & & \\
\hline Dorset & $\cdots$ & 2 & I I & 7 & 5 & 1 & I & - & $\ldots$ & - & I & -- & $1-$ & - & - & 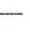 \\
\hline $\mathrm{m}$ & $\cdots$ & - & 8 & I & 4 & $\mid \mathbf{I}$ & - & - & & & & -1 & $3-$ & & & \\
\hline ex... & $\ldots$ & & 30 & 10 & 8 & $z$ & $\mathbf{I}$ & - & - & & $-5+2$ & $2 \ldots$ & 2 & - & & \\
\hline il & $\ldots$ & I & 9 & 4 & 8 & 2 & 2 & - & & - & I & $2-$ & $5-$ & & & - \\
\hline Hants. & $\ldots$ & 4 & $2 \mathrm{I}$ & 2 & & 2 & 2 & - & - & & 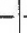 & -1 & 3 & & 1 & I \\
\hline ord & $\ldots$ & 5 & 12 & 4 & 6 & 1 & 1 & - & I & 2 & - & I- & 3 & - & - & I \\
\hline Herts & $\cdots$ & - & I0 & 3 & & - & $\pi$ & & - & & 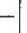 & $2-$ & $\mathbf{I}-$ & -1 & & \\
\hline Hunts & $\ldots$ & 5 & 12 & 4 & 6 & $\rightarrow$ & & & - & - & - & $1-$ & $\mathbf{I}-$ & - & - & - \\
\hline Kent & & 5 & 40 & 20 & 7 & 3 & 2 & - & & 一 & I & $-1-$ & & & & - \\
\hline Lancashire & & 2 & I6 & 7. & I I & $I$ & - & & - & I & - & 2 & & $2-$ & I & - \\
\hline Lei & $\ldots$ & 3 & 4 & 3 & 4 & - & -7 & - & - & & $\ldots$ & $1-$ & $\because 1$ & $I-$ & & - \\
\hline Lir & $\cdots$ & I & 16 & II & 9 & 2 & 2 & $\mathbf{I}$ & - & - & - & 12 & 12 & 2 & & \\
\hline Midd & $\ldots$ & - & 4 & - & I) & 1 & - & - & - & - & - & -1 & - & & & \\
\hline No & & 3 & 24 & II & I 3 & $\mathbf{I}$ & 2 & - & I. & $\ldots$ & I & & & & & - \\
\hline Northampl & & 6 & II & 5 & & $1-$ & - & 2 & - & 2 & & & & & & \\
\hline $\begin{array}{l}\text { Northum } \\
\text { land }\end{array}$ & & & & & & & & & & & & & & & & \\
\hline Nott & $\cdots$ & I & 6 & 2 & & - & 1 . & - & & & & & & $-1-5+3$ & - & \\
\hline Oxford & $\ldots$ & . & 7 & -1 & 5 & $I$ & I & & - & & - & & & & & - \\
\hline and & .. & - & I & - & & - & 1 . & -1 & - & - & & $-1-$ & $1=$ & - & - & 一 \\
\hline & $\ldots$ & 5 & 18 & 9 & 6 & $\mathrm{I}$ & - & I & & 2 & - & 2 & & $1-$ & - & I \\
\hline et & $\ldots$ & . & 27 & 25 & I.3. & 2 & 3 & - & $\mathbf{I}$ & & - & $\begin{array}{ll}5 & 1\end{array}$ & & - & - & I \\
\hline rd & $\ldots$ & 8 & 14 & 5 & ro & 3 & - & & - & $\mathbf{I}$ & - & $\mathrm{I}-$ & & $\mathbf{I}-$ & - & 2 \\
\hline Suffolk & $\ldots$ & 2 & 16 & 12 & & - & & - & & & - & 2 & & 1 & 1 & 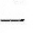 \\
\hline Surrey & & t & 16 & 5 & 6. & & - & L & & & . & I & & & & \\
\hline Sit & $\ldots$ & - & 51 & I2 & 12 & 2 & 2 & - & & & - & $8-$ & & & & \\
\hline ick & & 4 & 9 & 4 & 4 & I & 2 & 3 & 1 & & & & & & & - \\
\hline Westmor- & & & & & & & & & & & & & & & & \\
\hline & & - & 6 & & th & & & - & & & & I & & & & \\
\hline Wilts ... & $\cdots$ & 1 & I7 & Io & 2 & 6 & & & - & & & & & $\mathbf{I}=$ & & - \\
\hline & $\cdots$ & 2 & 4 & 4 & 1) & & & et & 6 & & & & & & & \\
\hline orks & & 15 & 42 & 22 & 26 & 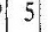 & 2 & -1 & 6 & & - & $\mathrm{I}$ & & $\begin{array}{lll} & \text { I } & \text { I }\end{array}$ & - & 3 \\
\hline & & & & 266 & & & & & & & & $1 \mathrm{I}$ & & 72 & & \\
\hline
\end{tabular}




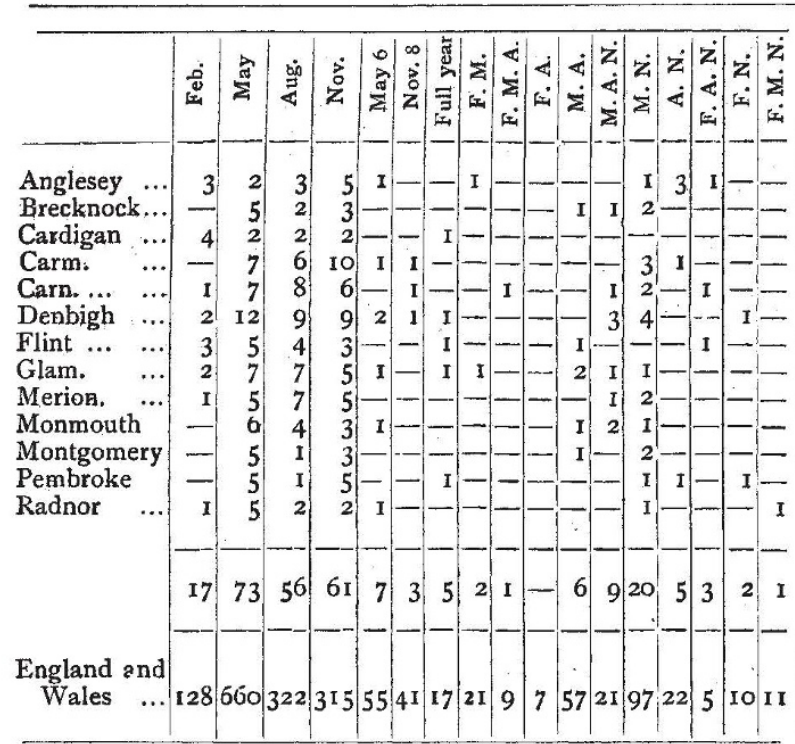

It is curious to note that the total of fairs in February, May, August, and November, with pre-Lenten and Whitsun fairs, is 1425 , just ten less than the total of true Mayyear fairs plus all the Church-year fairs which I would claim for that year. I can, therefore, add the Michaelmas and St. Andrew fairs to the last total obtained and make it I57I, or a round fifteen hundred May-year fairs, nearly two-thirds of the total number of solar, as distinguished from mere calendar, fairs.

Wales makes but a very poor show in Owen's list. Instead of five complete May-year series, I have noted ten in North Wales alone; but it serves the present purpose to keep Wales in the background.

It is satisfactory to find seventeen complete series. The case of Weldon, Northamptonshire, is eloquently put as follows :- "First Thursday in February, May, August, and November." There are, however, ten other combinations of May-year quarter days, each of which tells the same tale, and there are 277 places where the May-year seasons are observed by fairs, that is, where more than one Mayyear fair is held. The relative prevalence of the eleven combinations may be shown as follows:-

\begin{tabular}{|c|c|c|c|c|}
\hline & Feb. & May & Aug, & Nov. \\
\hline 17 & $\boldsymbol{I}$ & I & I & I \\
\hline 10 & I & - & - & I \\
\hline 21 & I & I & - & - \\
\hline 9 & I & I & I & - \\
\hline 7 & I & - & I & - \\
\hline 57 & - & I & I & - \\
\hline 2I & - & I & I & I \\
\hline 97 & - & I & - & 1 \\
\hline 5 & I & - & I & I \\
\hline 22 & - & - & I & $I$ \\
\hline II & I & I & - & I \\
\hline 277 & 7 & 7 & 7 & 7 \\
\hline
\end{tabular}

Each May-year quarter day enters into seven combinations, which reminds me of the story invented, I believe, to account for the popular name of the parish from which I write, $Y r$ Hên Blwyv, the Old Parish. The story goes that a stone-cutter carved the figure 7777 on a gravestone intended to commemorate a man whose age was twenty-eight. By the way, multiplying the May-year sevens together would be a good way to remember the number of solar fairs we have made out, 2303 for 2363 , leaving a margin of sixty for possible errors in such a large estimate.

Na combination of figures affects the supremacy of May Day. February enters into combination with other quarters at 80 places, May at 230, August at 139, and No. 1975 , vOL. 76$]$
November at 183 . Generally, the ratio seems to be:February $=1$, May $=3$, August $=2$, November $=2$.

But in the two most decisive factors there is not muck to choose between May and November. 'These two factors are the prominence of the summer half of the May year and the fact that the astronomical dates are still observed at ninety-six places in remarkably even numbers-May, 55 November, 4I. May 6 is associated with St. John the Evangelist. Such association may have helped to preserve the date; but no such Church sanction, favour, or support has been given to November 8 . There are four places in England where both dates are still observed. In several instances where the astronomical dates have been preserved I note a startling parallelism between the dates and the prominence acquired by those places in tradition and archæology.

List of Places where Fairs are held on May 6 and November 8.

Bedfordshire ... Nov. 8 ... Biggleswade.

Berkshire ... ... May 6 ... Abingdon, Aldermaster.

Nov. 8 ... Newbury.

Buckinghamshire May 6 . Buckingham, Ivinghoe, Ris. borough.

Nov. $8 \ldots$ Buckingham

Cheshire ... ... May 6 ...

Nov. $8 \ldots$ Knutsford (or Knotsford)

Cornwall ... ... May 6 ... Treganotha, West Looe.

Nov. 8 ... Helstone, Newlyn, Stratton.

Derbyshire $\quad \ldots$ May $6 \ldots$.... Pleaseley.

Nov. 8 ... Ripley.

Devonshire $\quad .$. May 6 ... Chawley, Tavistock.

Nov. 8 ... Hatherleigh.

Dorsetshire ... May 6 ...

Nov. 8 ... Blandford.

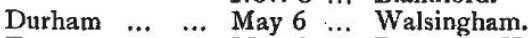

Essex $\quad . . . \quad \ldots$ May 6 ... Dunmow, Halstead.

$\begin{array}{llll} & \text { Nov. } 8 & \ldots & \text { Dunmow. } \\ \text { Gloucestershire } & \text { May } 6 & \ldots & \text { Dursley, Winchcomb. }\end{array}$

Nov. 8 ... Cirencester, Lydney.

Hampshire $\quad .$. May 6 ... Liss, Southampton.

Nov. 8 ... Blackwater, Rumsey.

Herefordshire ... May 6 ....

Nov. 8 ... Leominster.

Hertfordshire ... Nov. 8 ... Hertfard.

Kent ... ... ... May 6 ... Ashford, Groombridge.

Nov. $8 \ldots$ Biddenden, Chilham.

$\begin{array}{llllll}\text { Lincolnshire } & \ldots & \text { May } 6 & \text { May } 6 & \ldots & \text { Newton. } \\ \text { Le } & \text { Mourn, Holbeach. }\end{array}$

Nov. 8 ... Alford, Stamford.

Middlesex $\quad . . . \quad$ May $6 \ldots$...

Norfolk $\ldots$ May $6 \ldots$ Rudham.

Nov. 8 ... Diss, Massingham.

Northumberland Nov. 8 ... Hexham.

Nottinghamshire Nov. 8 Bingham.

Oxfordshire ... May 6 ... Chipping Norton.

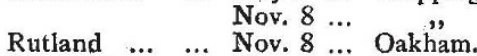

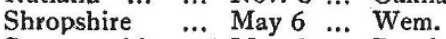

Somersetshire ...

Nov. 8 ... Dulverton, Pensford, Somerton.

Staffordshire ... May 6 ... Uttoxeter, Wednesbury, Long

Suffolk $\quad \ldots \quad \ldots \quad$ Nov. $8 \ldots$ Newmarket.

Sussex $\quad \ldots . \quad \ldots$ May 6 ... Lewes, Bolney.

Nov. 8 ;... Billinghurst, Forest Row.

Warwickshire ... May 6 ...

Nov. 8 ... Sutton, Warwick.

Westmorland ... Nov. 8 ... Kendal.

Wiltshire ... ... May 6 ... Amesbury, Colne, Maiden Bradley, Chippenham, Mere, Purten.

Yorkshire ... ... May 6 ... Hunmanby, Knaresborough, Pocklington, Askrig, Burton in Bishopdale.

Wales ... ... May $6 \ldots$ Langharne, Llannerchymedd, Nantglyn, Hay, Penrice, Knighton:

Nov. 8 ... Aberconway, Llanedi, Llanrhaiadr. 
From other sources I find six more May 6 fairs in Wales and three November 8 fairs, in all twelve of the former and six of the latter. Only in one place, Llanfynydd, Carm., I find both days observed.

Pensford, where both dates are retained, is near Stanton Drew, where Sir Norman Lockyer has made out a May alignment. At Lydney, Gloucestershire, a Roman inscription has been found to the Celtic Neptune, Nudd or Lludd. At Hexham a similar inscription equates Apollo with the Celtic god Maponos. Dunmow's flitch of bacon should be carefully studied.

I think all will admit that the phrase "startling parallelism" is no exaggeration when the case of Wiltshire is considered. When Sir Norman Lockyer ascertained the age of Stonehenge from the alignment of the avenue, he found evidence there of an earlier May-year temple. Geoffrey of Monmouth fixes the earliest festival he mentions as having been held at Stonehenge on the Kalends of May. That must have been against his liking as an ecclesiastic, and the next festival, held shortly after the first, he fixes at. Pentecost, the Church equivalent of the-May festival; but Geoffrey never fixes a Church festival where and when such a festival was an historical impossibility. Therefore it is practically certain Stonehenge was a May temple pure and simple in the fifth century A.D.

Now Wiltshire heads the record with six fairs on May 6 and its equivalent May i7. So the astronomical, historical, and ferial evidences point clearly to the preeminence of Stonehenge as a May temple. No wonder the Welsh bards claim it as one of the three chief Gorsedds.

But what of the manifestly solstitial character of the present ruins at Stonehenge? In Wiltshire seventeen out of thirty May-year fairs are held in May, but the May year as such is nearly non est. May and August combine in one place; that is all. On the other hand, the solstitial year in the county is a fairly well-balanced year. There are five fairs held on the vernal equinox, five on the summer solstice, eleven on the autumnal equinox, and three on the winter solstice, the last figure being quite significant, as definite winter solstice fairs are very rare, though, of course, as Christmas, it has no rival.

Now, the local fairs connect the two series of facts in the most striking manner. "Amesbury, May I7, June 22." So does Owen solve the riddle of Stonehenge. Chippenham, May 17, June 22. Maiden Bradley, May 6, October 2 (O.S. for September 21). Mere, May 17, October Io (O.S. for September 29, here very likely September 2I at first). Ignoring the date May 6, we have many other like combinations, ${ }^{-}$February I4-October 2, May 14September 25, July 10-August I, May 14-October 10, May 12-October 2, May 20-September 23-December 23, May 7-October 8. At Laycock we have only the two solstices July 7-December $2 \mathrm{r}$.

Since the foregoing tables were compiled, I have discovered that" the estimates' for both the.. May and the solstitial years are much too low, even on the incomplete showing in Owen's list. The astronomical date is to be looked for not only, eleven days later, as, for instance, May i7 at Ámesbury for May 6, but also eleven days earlier. When immediately before I752-A.D. the solstice was the eleventh,' the date corresponding to our May 6 would be April 26. In 1824 there was a remarkable series of fairs eleven days before the May-year quarter-days proper. This came out while I. was searching for some explanation of the strange fact that there is not a single fair on February 4. I find them under. January 25. August 5 is the thost popular survival of the old August quarter day, and the equivalent of that date.is July 25 , and that of 'November s is Octóber. 29. As the tables given above are sufficient to show the distribution and relative prevalence of May-year fairs, it may suffice to add only the places where the overlooked series of fairs is found.

January 25 (February 4),-Bentham, Bingley, Bodmin, Chesterfield, Churchingford, Derby, Kington (Warwickshire), Weasenham, Whittlesea in the Isle of Ely. (Nine fäirs:)

April 23 (May 4).-Bewdley, Billesden, Bruton, Campden, Downton, Finchampstead, Great Bedwin, Hatfield, Hinton St. Geor'ge, Holywell, Manhineot, Methwould, Norlease, Oakingham, Sawbridgeworth, Stanaway, Tenbury, Yetminster. (Eighteen fairs.)
April 25 (May 6).-Ashover, Bracknell, Brigstock, Burnham (Essex), Crowborough, Dronfield, Great Oakley, Holt (Norfolk), Iron-Acton, Llandegla, Llannerchymedd, Llanrwst, Limpsham, Loughborough, Medhurst, Methwould, Parkgate, Stoke-under-Hampden, Toddington, Warkworth. (Twenty fairs.)

April 25 and 26 (May 6).-Kendal, Penrith. (Two fairs.) April 26 (May 6).--King's Norton, Ovingham, Settle. (Three fairs.)

April 27 (May 6).-Axminster, Boroughbridge, Cerrig y Druidion, Dorston (Heref. There is a cromlech there), Holdsworthy, Keynsham, Mortimer, Spalding, South Molton. (Nine fairs.)

April 28 (May 6).--Boroughbridge, Cerne-Abbas, Keynsham, Malmesbury, Soham. (Five fairs.)

I claim April 23 because of the popularity of May 4. The two-days' fairs at Kendal and Penrith connect April 25 and 26 with May 5 and 6 . I claim April 27 and 28 for a similar reason, namely, that both at Boroughbridge and Keynsham there are two-days' fairs held, which must have been old May festivals. We have the first. and the last day of the three-days' festival in the fairs at Methwould on April 23 and 25 .

There are only two fairs on August 8, Rhuthin and Shepton Mallet, and there are only two fairs on the equivalent date, July 29, Mountsorrel and Wivelsfield. Mountsorrel is an interesting name, as, I believe, some authorities hold that the wood-sorrel was the original shamrock, which we have reason to claim as a May-year emblematic plant. The great August fair day is the fifth, which we are sure was one day of the August festival because it is coupled with the sixth in two-days' fairs at Ewhurst, Goldsithnay, Louth, and Trowbridge.

July 25 (August 5).-Acle, Alresford, Ashton-under-Lyne, Barnard Castle, Billesdon, Blackboys, Castle-Acre, Little Clacton, Derby, Dunwich, Earith, Gissing, Great Wakering, Hockwold, Ipswich, Leigh (Kent), Lindsey, Liverpool, Middlewich, Milverton, North Down, Reading, Saltash, Seaford, Shoreham (Sussex), Southrepps, Staple, Tiptree Place, Totnes, Tregony, Trew, Wisbech (Isle of Ely), Wells, Yarmouth (Isle of Wight). (Thirty-four fairs.)

July 26 (August 8).-Bewdley, Clare, Great Bedwin, Hastings, Horsemonden, Kirby, Lewes, Llanelian, Llansawel, Leighton Buzzard, Malpas, Mattingley, Newnham (Kent), Portsdown, Sherborne, Tamworth (Staff.), Twyford. (Seventeen fairs.)

July 28 (August 8).-St. Kenelm's, Leek, Manhineot, Week St. Mary, Winchcomb. (Five fairs.) '(I claim this date on the strength of the correspondence of the Manhineot July fair with that on April 23.)

The fairs in October are very numerous. From the 20 th to the 29th I recognise familiar May-year places, such as Cerrig y Druidion, Sawbridgeworth, and Wells on the 2oth; Boroughbridge and Llansawel on the 23rd; Leighton Buzzard on the $24^{\text {th }}$; Bentham and Wells on the $25^{\text {th }}$.

October 26 (November 8).-Appletreewick (an excellent name), Grantham, Edwinstone, Llandegla, Llansannan, Ovingham, Pen y Bont (Radnor), Spalding, Warminster, Whittlesea in the Isle of Ely. (Ten fairs.)

October 27 (November 8).-Abergwili, Appletreewick, Caergwrle, Cleobury-Mortimer, Darley-Flash, Daventry, March in the Isle of Ely, Nantglyn. (Eight.fairs.)

October 28 (November 8).-Alnwick, Askrig, Bangor, East Dean, Llanidloes, Lifton, Linfield, Milbourne-Port, Needham, Plympton, Radnor, South Harting, Thirsk, Totnes, Warminster, Whitchurch (Salop), Wigan. (Seventeen fairs.)

October 29 (November 8 strictly).-Abbey-Holm, Ambleside, Askrig, Bourn, Little Brickhill, Bridgenorth, Broadwater, Burton, Chaford, Charing, Chippenham, Clay, Ely, Ewell, Farringdon, Halstead, Hampton (Gloucestershire), Henley-in-Arden, Highworth, Hindon, Holt (Denbighshire), Horncastle, Hunmanby, Kidwelly, King's Cliff,. Kirkby Stephen, Saint Lawrence (Cornwall), Marlow, Midhurst, Mongham, Newcastle-upon-Tyne (nine days), Pamphill, Pleasley, Radnor, Sedburgh, Tenby, Thirsk, Tidswell, Towcester, Tunbridge, Uphaven, Usk, Wellingborough Wigan, (Forty-four fairs.)

Without making any further attempt at estimating the number of May quarter-day fairs, we must count nine fairs on January 25 as February 4 festivals; add 57 to the $3^{8}$ 
on May 6, in all 95 fairs which are strictly May 6 fairs; add 56 to the 53 on August 5, and regard them all as strictly August 8 fairs; and add 79 to the 43 on November 8 , though there are more fairs in October claiming such recognition.

Our lowest possible estimate of true May-year fairs is now as follows :-

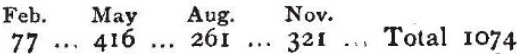

$\begin{array}{llllllllllllll}\text { Astronomical } & 35 & \ldots & 96 & \ldots & 109 & \ldots & 122 & \ldots & , & 362\end{array}$

The table of the quarter-day groups must likewise be corrected, only to strengthen materially the whole case for the May-year. (Only in a few cases have I been able to correct Owen's spelling of place-names.)

\section{川}

The Bardic Mystic Sign. (Reproduced from "Barddas." "Morien " quotes Payne Knight's "Symbolical Language of Art and Mythology," pp. 69,70 , where it is stated that the same sign, with a small circle or ring at the converging point of the three lines, is a very ancient emblem in Asia Minor. The angles in Knight's sketch, as reproduced by "Morien," are also exactly $28^{\circ}$ each.)

George Meredith makes one of his Welsh characters "think in triads." Here is a new triad:- "The three interpreters of the riddle of the stones: the Sun, the Gorsedd, and the Popular Fair." I have already shown (NATURE, May 2) that the May year is the true basis of the Gorsedd. The bardic Nod Cyvrin, Mystic Sign, which Mr. A. L. Lewis (Nature, June 6) associates very naturally with the "broad arrow," is really a miniature Gorsedd. I have tested several printed cuts of the sign and find the angles to be $28^{\circ}$, that is, regarding the middle line as an east-west line, the right line points to N. $62^{\circ} \mathrm{E}$. and the left to $\mathrm{S} .62^{\circ} \mathrm{E}$., the only possible emblematic representation, in the simplest form, of the May year in the Gorsedd country. JoHN GRIFFITH.

\section{KATHODE RAYS AND THE AURORA.'}

THE idea that kathode rays play a part in aurora has been advanced by several physicists. Prof. $\mathrm{Kr}$. Birkeland " Expedition Norvegienne," I899-1900, Christiania, 1901) has escribed 2 number of phenomena produced by kathode ras in the for ghbourhood of a magnetised sphere, which resentele various types of aurora. He supposed the sun to b Aprimary source for kathode rays, which might set up secondary rays in the earth's atmosphere. Mr. C. Stormer has carried out elaborate calculations as to the possible ways in which electrified particles coming from a great distance can approach a magnetised "earth"; his

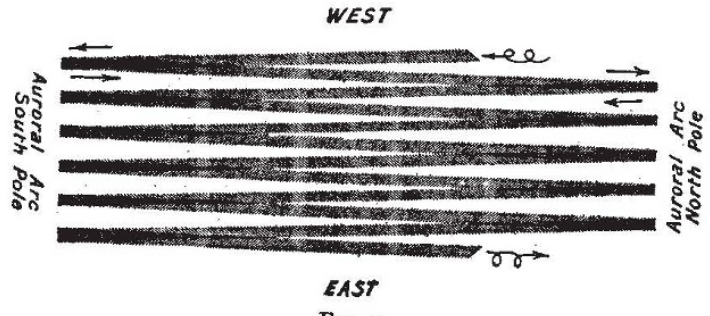

Fig. I.

results tend to limit the approaching particles to the space near the magnetic poles. Prof. S. Arrhenius has supposed electrified particles' to be driven from the sun by the repulsion of light and to reach the earth's atmosphere in about two days, originating aurora and magnetic storms.

M. Villard refers to Arrhenius's theory, but seems somewhat sceptical as to the supposed solar origin of the electrified particles. His own views appear to be a combination of theory and observation as to what happens to ions or electrified bodies of any kind moving in a magnetic field. In a uniform field the ion, when travelling with uniform velocity, describes a regular helix on a cylinder the axis of

I “Les Rayons cathodiques et l'Aurore boréale." By M. P. Villard. (Bulletin de la Société d'Encouragement pour l'Industrie nationale, May, ro07.).

No. I975, VOL. 76] which is parallel to the lines of magnetic force. The radius of the cylinder varies directly as the component of the velocity perpendicular to the lines of magnetic force, and inversely as the intensity of the field. Suppose, however, that the magnetic field is not uniform, but increases in intensity in the direction in which the ion travels; then, as has been shown by Poincaré, the path forms a curve with diminishing spirals on a cone, and before actually reaching the summit of the cone the particle ceases to advance, and retires, the spirals gradually opening out. If, for instance, the field is that due to two elongated parallel poles, then if the particle gets under weigh between the poles, travelling obliquely to the lines of force, there is a regular game of battledore and shuttlecock, the particle zigzagging to and fro slantwise, reversing its direction whenever it gets within a certain distance of either pole.

M. Villard supposes ions to get in motion somewhere in the earth's atmosphere. As to exactly how this comes about he is not prepared to dogmatise. He.is inclined to think that cirrt's.clonds-which he believes to consist of ice partiches negatively electrified-under the influence of ultraviolet light, or less probably under a solar bombardment such as Arrhenius postutes, are probable sources. He also thinks that not improbabry a part is played by cosmical dust encountered in the earth's novement through space. Ions starting, say, from a cirrus cloutd, and moving obliquely to the lines of magnetic force in the rafth's atmosphere, will travel each in a spiral, the whole together forming a sort of luminous spindle, which on getting within a certain distance of, say, the south magnetic pole, turns as if reflected, makes for the north pole, suffers a second reflection there, and so on. Fig. I, copied from M. Villard's paper, represents the idea diagrammatically. The particles are supposed to come in at the top (answering to the west) and first to traval south. The movement may be supposed to be set up by ultra-violet light from the sun falling on cirrus. The first band or two will thus be in the still illuminated hemisphere, and so invisible; succeeding bands will be overhead in the unlighted hemisphere, and will be visible. Passing further to the east, the energy will be gradually dissipated and the aurora ccase to be visible, thus explaining why the late evening, and not the morning, is normally the time of most brilliant aurora.

To fit the theory, the charge carried by the particles must be negative. If it were positive, the motion would be from the east, and the principal aurora would be in the early morning. Fig. 2 reproduces a photograph showing the actual appearance near a magnetic pole from one point of view, in one of M. Villard's experiments. He regards the intensifications of brightness, due to the superposition

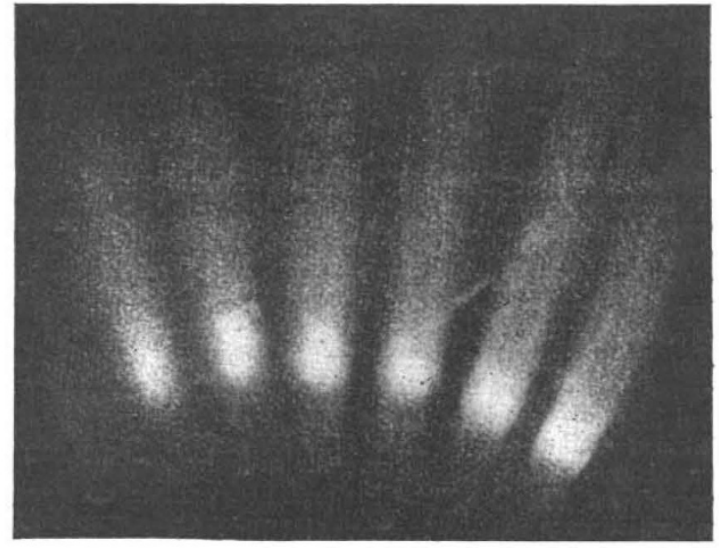

FIG. 2.

of the direct and return paths, as answering to an auroral arc. Below the arc there would, he says, be total darkness-answering to the "dark segment" of the ordinary aurora-but for a special form of discharge which he terms " magneto-kathodic" rays; these rays require, he says, a very steep potential gradient, and do not exist in the earth's atmosphere. Changes in the magnetic field or 